\section{Tensiometric Monitoring of Container Substrate Moisture Status}

\author{
Roberto Testezlaf, ${ }^{1}$ \\ Claudia A. Larsen, ${ }^{2}$ \\ Thomas $\mathrm{H}$. Yeager, ${ }^{2}$ and \\ Fedro S. Zazueta ${ }^{1}$
}

\begin{abstract}
ADDITIONAL INDEX WORDS. ornamental plants, irrigation

Summary. The objective of these experiments was to evaluate the use of tensiometers to monitor substrate moisture tensions for $M$ etro-M ix 500 and 2 pine bark : $1 \mathrm{C}$ anadian peat : 1 sand (PBPS, by volume) used for container-grown azalea $R$ hododendron indicum L. 'M rs. G.G . Gerbing' and chrysanthemum (D endranthema grandiflora T zvelez.) 'C oral Charm.' Commercially available ceramic cups of two sizes, small [0.374 inch $(0.95 \mathrm{~cm})$ diameter and 1.125 inches $(2.86 \mathrm{~cm})$ long] and large [0.874 inch $(2.22 \mathrm{~cm})$ diameter and 3.0 inches $(7.62 \mathrm{~cm})$ long] were used to construct pressure transducer-equipped tensiometers. $D$ ata from these greenhouse experiments, indicate that either the small or large ceramic cup could be used to monitor substrate tensions at which water would be available to containergrown plants.
\end{abstract}

$\mathrm{P}$ revious research with container-grown plants indicated that multiple applications of water each day resulted in more growth than asingleapplication (Beeson,

The authors acknowledge the support provided by Sao Paulo State Research Foundation (FAPE SP)-Brazil for granting funds to the first authors' scholarship. M ention of trade names does not constitute an endorsement nor discrimination for similar products not mentioned. Florida Agricultural Experiment Station J ournal series No. R-06069. The cost of publishing this paper was defrayed in part by the payment of page charges. U nder postal regulations, this paper therefore must be hereby marked advertisement solely to indicate this fact.

${ }^{1} V$ isiting professor and professor, respectively, Agricultural and Biological Engineering D epartment, U niversity of Florida, Gainesville, FL 32611.

${ }^{2}$ Senior biological scientist and professor, respectively, D epartment of Environmental $\mathrm{H}$ orticulture, U niversity of Florida, Gainesville, FL 32611.
1992). Thesubstratethat received multiple applications would contain more water before an irrigation event than substrate that received a single irrigation and thiscould result in more of the applied water being absorbed by the substrate (Karam and N iemiera, 1994). To maximize the usefulness of thisconcept, real-time substrate moisture measurements are needed to schedule irrigation. This could be accomplished with a substrate moisture sensor and irrigation control based on preset substrate moisture tensions. Richards and $M$ arsh (1961) used tensiometers to schedule irrigation and to indicate the amount of water to apply with each application. Pogue and Pooley (1988) recommended the use of tensiometers for managing any low volumeirrigation system and as an essential tool to maximizewater usage, crop vigor, yields, and plant quality.

Tensiometers measure soil matric potential, which can be related to soil moisture content. They are relatively inexpensive, but have a limited operating range $[0$ to 0.8 bar $(80 \mathrm{kPa})$ of suction], a response lag time, require continuous maintenance, measure tension and not soil moisture, and require good contact with the soil or substrate.

Pressure transducers can be easily attached to tensiometersfor digital conversion and data acquisition. Factors, such as, temperatureand substratephysical conditions, entrapped air, and permeability of the ceramic can affected the responsetime of atensiometer-pressure transducer system (Stone et al., 1986; Watson, 1967; Watson and Jackson, 1967). Tensiometer-mounted pressure transducer devicescan beinterfaced with microcomputer-based data acquisition and control systems for real-time monitoring of soil water potential (M eron et al., 1995; Stoneet al., 1985; T estezlaf et al., 1996; Vellidis et al., 1990; Zazueta et al., 1985). Pheneet al. (1988) recommended the use of real-time irrigation control for production systems characterized as high frequency scheduling, which is typical for greenhouse production. In this case, a real-time control system has the potential to result in water conservation.

Real-time measurements have not been used extensively in the ornamental horticultureindustrybecause of thelack of technical information and adequate sensors. In container plant production, tensiometersarevery sensitive to disturbances that result in loss of contact with 


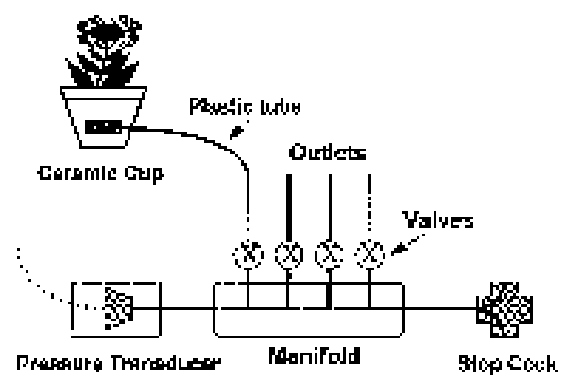

Fig. 1. Layout of the manifold setup used to monitor substrate moisture tensions of azalea ( $R$ hododendron indicum) 'M rs. G.G . G erbing' and chrysanthemum ( $D$ endranthema grandiflora) 'C oral C harm.' The pressure transducer was interfaced with computer software to enabled real-time evaluation of substrate moisture tension.

the substrate (Valiente, 1993). D espite this limitation, tensiometers have been used in potted plant production to automatically scheduleirrigation at different moisturetensions(Burger and Paul, 1987; Lieth and Burger, 1989; T estezlaf et al., 1996). Zazueta et al. (1994) developed a modified tensiometer in which the substrate rested on a porous plate. The objective of our study was to evaluate two different sizes of ceramic cups positioned horizontally to monitor the moisture tension of two substrates.

\section{Materials and methods}

EquipMent. T wo sizes of ceramic cups $[0.374$ inch $(0.95 \mathrm{~cm})$ diameter and 1.125 inches $(2.86 \mathrm{~cm})$ long and 0.874 inch $(2.22 \mathrm{~cm})$ diameter and 3.0 inches $(7.62 \mathrm{~cm})$ long] were used to construct pressuretransducer-equipped tensiometers. Thelargecupsweretaken from standard 1-bar (100-kPa) tensiometers (model 2710-ARL; Forestry SuppliesInc., J ackson, M iss.). T hesmall cups were also 1 bar (Q-Com, Inc., I rvine, Calif.)]. $M$ anifold systems with four outlets each were built to connect four tensiometer probes to one pressure transducer. In Fig. 1, is a layout of the manifold setup. A medical three-way stopcock (Baxter H ealthcare Corp., Valencia, Calif.) was installed in each manifold. This device was used for a syringe access to purge the system.

The piezoresistive-type pressure transducers (M PX5100 D P; M otorola Semiconductor Products Inc., Phoenix, Ariz.) were chosen based on their low cost, high level analog output, operating pressure range, and accuracy
[ $\pm 2.5 \%$ over 0 to $\left.185^{\circ} \mathrm{F}\left(85^{\circ} \mathrm{C}\right)\right]$. The pressure range of these transducers is from 0 to -1 bar $(-100 \mathrm{kPa})$ and producesan analog electrical output from 0 to $5 \mathrm{v}$ for $5 \mathrm{v}$ direct current (VDC) supplied voltage. The voltage-pressure regression of the transducer's response was linear $\left(R^{2}=0.99\right)$ and significant at $1 \%$ (Testezlaf et al., 1997). To ensure adequate power to the transducers, a separate regulated power supply was used during the experiments.

A data acquisition and control system (model 570; Keithley M etrabyte, Cleveland, 0 hio) with 12 bits resolution with 16 differential input channels, was used for data acquisition. A graphical user interface developed and evaluated by T estezlaf et al. (1995) was used to continuously monitor the soil moisture tension.

EXPERIMENTAL DESIGN. Two experiments were established separately for two container-grown species, azalea (R . indicum ) 'M rs. G.G. Gerbing' and chrysanthemum (D.grandiflora) 'C oral Charm.' Both experiments consisted of factorial combinations of tensiometer ceramic cup sizes (small and large) and container substrate type (commercial and grower blended substrate). Four plants were randomly assigned to each of four pressure transducer assemblies, and these units were arranged in a completelyrandomized design. Experiments were conducted under greenhouseconditions at the University of Florida, Gainesville.

EXPERIMENT 1. On 12 Feb. 1996, multiplebranched linersof azalea('M rs. G.G. Gerbing') plants were potted in 3.4-qt $(\approx 3-L)$ nursery containers [ 6.25 inches $(15.8 \mathrm{~cm})$ diameter by 6.50 inches $(16.5 \mathrm{~cm})$ ] using either M etro-M ix500

T able 1. C umulative water loss ( $\mathrm{g}$ ) for azalea (R hododendron indicum) 'M rs. G.G. G erbing' grown in 3.4-qt (3-L) containers with either a 2 pine bark : 1 Canadian peat : 1 sand substrate (PB PS, by volume) or M etro-M ix 500 (M M) with small or large ceramic cups $(n=4 \pm S D)$.

\begin{tabular}{lcccc}
\hline Day & Small/PBPS & Small/M M & Large/PBPS & L arge/M M \\
\hline 0 & $0 \pm 0$ & $0 \pm 0$ & $0 \pm 0$ & $0 \pm 0$ \\
1 & $24 \pm 11$ & $30 \pm 14$ & $57 \pm 31$ & $53 \pm 27$ \\
2 & $85 \pm 17$ & $96 \pm 16$ & $111 \pm 26$ & $88 \pm 34$ \\
3 & $140 \pm 27$ & $145 \pm 21$ & $149 \pm 19$ & $138 \pm 20$ \\
4 & $232 \pm 40$ & $264 \pm 48$ & $251 \pm 54$ & $242 \pm 12$ \\
5 & $347 \pm 52$ & $389 \pm 34$ & $375 \pm 49$ & $343 \pm 36$ \\
6 & $419 \pm 42$ & $475 \pm 41$ & $442 \pm 45$ & $420 \pm 46$ \\
7 & $486 \pm 46$ & $547 \pm 55$ & $507 \pm 30$ & $480 \pm 50$ \\
8 & $572 \pm 54$ & $643 \pm 54$ & $592 \pm 46$ & $563 \pm 60$ \\
9 & $650 \pm 59$ & $741 \pm 49$ & $683 \pm 47$ & $650 \pm 73$ \\
10 & $717 \pm 56$ & $817 \pm 45$ & $748 \pm 32$ & $738 \pm 75$
\end{tabular}

2Small $=$ diameter of 0.374 inch $(0.95 \mathrm{~cm})$ and length of 1.125 inches $(2.86 \mathrm{~cm})$. Large $=$ diameter of 0.874 inch $(2.22 \mathrm{~cm})$ and length of 3.0 inches $(7.62 \mathrm{~cm}) ; 10 \mathrm{~g}=0.35 \mathrm{oz}$.

(Scotts-Sierra H orticultural Products Co., M arysville, Ohio) or 2 blended pinebark : 1 Canadian peat : 1 sand mix (PBPS, by volume). Valiente (1993) determined the physical properties of both container substrates. The plants werewatered and placed in aglassgreenhouse $\left(\approx 450 \mu \mathrm{mol} \cdot \mathrm{m}^{-2} \cdot \mathrm{s}^{-1}\right)$ set for $54^{\circ} \mathrm{F}$ $\left(13^{\circ} \mathrm{C}\right)$ night temperature and $84^{\circ} \mathrm{F}$ $\left(29^{\circ} \mathrm{C}\right)$ day temperature. $D$ aily irrigation was supplied as needed and a solution that contained (in ppm) $150 \mathrm{~N}, 10$ $\mathrm{P}$, and $30 \mathrm{~K}$ from $\mathrm{NH}_{4} \mathrm{NO}_{3}, \mathrm{KH}_{2} \mathrm{PO}_{4}$, and $\mathrm{K}_{2} \mathrm{SO}_{4}$ was applied weekly. The bench was lit with intermittent incandescent light 2200 to $0200 \mathrm{H} \mathrm{R}$ to stimulateroot and shoot growth. When roots were visible on $50 \%$ of the substrate surface, the experiment was initiated.

Eight plants of similar development and sizethat were potted in M etro$M$ ix 500 and eight that were potted in PBPS were selected. From each group of eight, four containers were prepared with tensiometers with small cups, and four with large cups by drilling a hole in the container plastic wall using a wood boring spade bit. The manifold system was carefully purged and tensiometers were inserted horizontally in the center of the substrate. Diameter of holes facilitated a snug fit around the tensiometers. Four randomly chosen containers were assigned to each manifold. All container substrates were saturated for $24 \mathrm{~h}$ and drained for $2 \mathrm{~h}$ before experiment initiation. Container weights and substratetensionswere monitored during one dry cycle, from 4 to $14 \mathrm{M}$ ar. 1996. Theend of adry cyclewas defined when most plants showed wilting.

EXPERIMENT 2. On 22 Feb. 1996, chrysanthemum ('Coral Charm') plugs were potted (four per pot) in standard 
Table 2. T ension readings ( $\mathrm{kPa}$ ) for azalea ( $\mathrm{R}$ hododendron indicum) 'M rs. G.G. G erbing' grown in a 3.4-qt (3-L) containers with either a 2 pine bark : 1 C anadian peat : 1 sand substrate (PB PS, by volume) or M etro-M ix 500 (M M) with small or large ceramic cups ${ }^{2}(n=4 \pm$ SD).

\begin{tabular}{lcccc}
\hline Day & Small/PBPS & Small/M M & Large/PBPS & L arge/M M \\
\hline 0 & $1.0 \pm 0.6$ & $0.9 \pm 0.4$ & $0.8 \pm 0.6$ & $0.9 \pm 0.5$ \\
1 & $1.3 \pm 0.7$ & $1.1 \pm 0.5$ & $1.0 \pm 0.3$ & $1.1 \pm 0.3$ \\
2 & $1.2 \pm 0.4$ & $1.1 \pm 0.4$ & $1.1 \pm 0.3$ & $1.3 \pm 0.3$ \\
3 & $1.4 \pm 0.4$ & $1.4 \pm 0.4$ & $1.3 \pm 0.4$ & $1.3 \pm 0.4$ \\
4 & $1.7 \pm 0.4$ & $1.9 \pm 0.6$ & $1.5 \pm 0.4$ & $1.5 \pm 0.5$ \\
5 & $2.1 \pm 0.4$ & $2.5 \pm 0.2$ & $2.0 \pm 0.4$ & $2.2 \pm 0.3$ \\
6 & $2.9 \pm 0.7$ & $3.8 \pm 0.7$ & $2.5 \pm 0.2$ & $2.4 \pm 0.7$ \\
7 & $3.3 \pm 0.4$ & $4.6 \pm 0.2$ & $3.2 \pm 0.5$ & $3.5 \pm 0.8$ \\
8 & $6.0 \pm 2.1$ & $7.3 \pm 0.9$ & $5.7 \pm 1.0$ & $5.1 \pm 2.3$ \\
9 & $10.0 \pm 4.8$ & $8.6 \pm 2.6$ & $8.6 \pm 1.7$ & $6.2^{\mathrm{y}}$ \\
10 & $7.7 \pm 2.3$ & $6.3 \pm 2.4$ & $9.3 \pm 2.6$ & $7.4^{\mathrm{y}}$
\end{tabular}

${ }^{2}$ Small $=$ diameter of 0.374 inch $(0.95 \mathrm{~cm})$ and length of 1.125 inches $(2.86 \mathrm{~cm})$. Large $=$ diameter of 0.874 inch $(2.22 \mathrm{~cm})$ and length of 3.0 inches $(7.62 \mathrm{~cm}) ; 1 \mathrm{bar}=100 \mathrm{kPa}$. $\mathrm{y}_{\mathrm{n}}=1$.

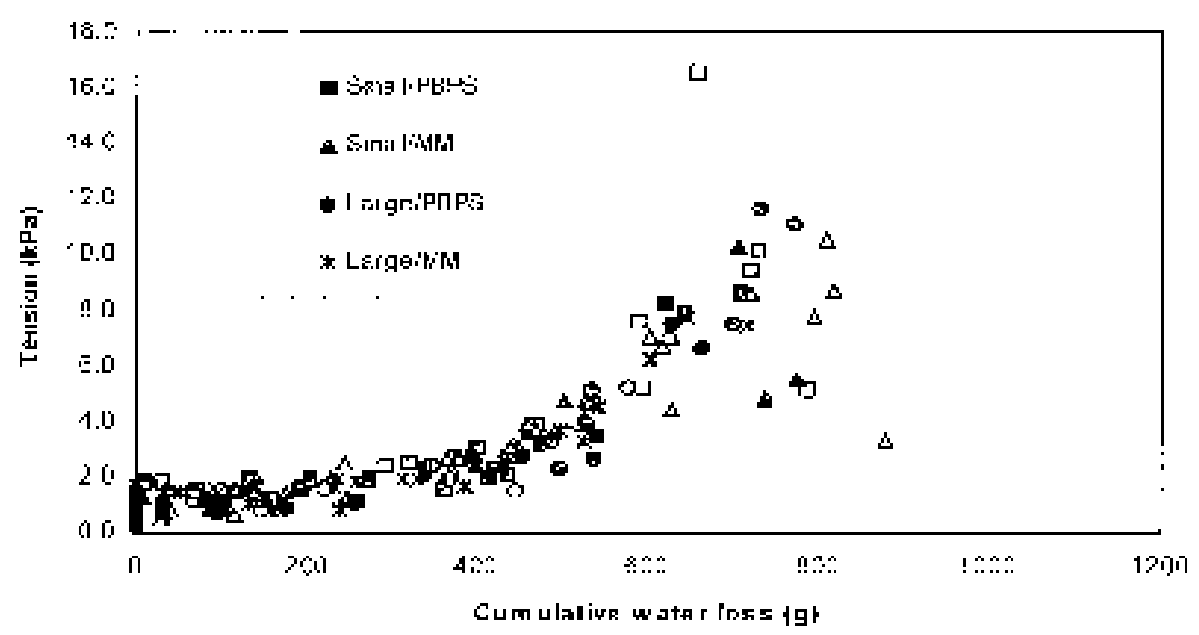

acquisition system, at the samemoment weight readings were made. Each time themanifold position waschanged for a container tension reading, a waiting period of 3 to 6 min was necessary for signal stabilization.

The cumulative daily water loss was determined by subtracting the weight obtained each day from the initial weight. To evaluate the effects of ceramic cup sizeand substrate, an analysis of variance was performed for each day. A variable called percent of cumulative water loss (PCWL) was estimated to evaluate the relationship between daily water loss and substrate water tension. It describeshow much of the total container capacity was left in the container every day during the dry cycle. It is cal culated by PCWL $=\left[\left(\mathrm{W}\left(\mathrm{cWl}-\mathrm{W}_{\mathrm{i}}\right) /\right.\right.$ $(\mathrm{Wcwi})] \times 100$, where $\mathrm{Wcwl}=$ total cumulative water loss in grams and $\mathrm{W}_{\mathrm{i}}=$ cumulative daily water loss in grams at day i.

This variable was related to corresponding tension values by using an exponential function.

\section{Results and discussion}

EXPERIMENT 1. There was not a significant interaction between substrate type and sensor cup size for cumulative water loss or tension readings for each day. Cumulative water losseach day was not different due to substrate, and tension readings each day were not different dueto sensors, except for day $6(P=$ 0.015). D ata for each day are shown in
Fig. 2. R elationship between substrate tension ( $\mathrm{kPa}$ ) and cumulative water loss for azalea ( $R$ hododendron indicum) 'M rs. G.G . G erbing' with small [diameter of 0.374 inch $\mathbf{0 . 9 5}$ $\mathrm{cm})$ and length of 1.125 inches (2.86 $\mathrm{cm})$ ] or large [diameter of 0.874 inch $(2.22 \mathrm{~cm})$ and length of 3.0 inches $(7.62 \mathrm{~cm})$ ] ceramic cups in 2 pine bark : $1 \mathrm{C}$ anadian peat : 1 sand (PBPS, by volume) or Metro-Mix 500 ( M M) 1 bar = $100 \mathrm{kPa}$.

3.4-qt nursery containersusing the same two substrates. The same experimental procedure defined for azalea was used for chrysanthemum. Container weights and substrate tensions were monitored for two dry cycles, from 15 to $22 \mathrm{M}$ ar. 1996 and from $27 \mathrm{M}$ ar. to $3 \mathrm{~A}$ pr. 1996.

DATA ACQUISITION AND ANALYSIS. $D$ aily afternoon measurements of container weightswere made using a digital balance $(\approx 1.0 \mathrm{~g})$. Corresponding tension readingswere obtained by the data

Horthechnology • J anuary-M arch 1999 9(1)
Table 3. C umulative daily water loss for chrysanthemum ( $D$ endranthema grandiflora) ' $C$ oral $C$ harm' grown in 3.4-qt (3-L) containers with either a 2 pine bark : 1 C anadian peat : 1 sand substrate (PBPS, by volume) or M etroMix 500 (M M) with small or large ceramic cups $(n=4 \pm$ SD).

\begin{tabular}{lcccc}
\hline Day & Small/PB PS & Small/M M & Large/PBPS & L arge/M M \\
\hline & & Water loss (g) & for first cycle & \\
0 & $0 \pm 0$ & $0 \pm 0$ & $0 \pm 0$ & $0 \pm 0$ \\
1 & $96 \pm 29$ & $81 \pm 26$ & $86 \pm 4$ & $116 \pm 9$ \\
2 & $196 \pm 25$ & $221 \pm 25$ & $196 \pm 9$ & $257 \pm 14$ \\
3 & $250 \pm 20$ & $291 \pm 26$ & $244 \pm 23$ & $335 \pm 12$ \\
4 & $379 \pm 35$ & $445 \pm 36$ & $353 \pm 26$ & $496 \pm 21$ \\
5 & $456 \pm 38$ & $580 \pm 51$ & $441 \pm 17$ & $641 \pm 28$ \\
6 & $584 \pm 46$ & $720 \pm 39$ & $551 \pm 29$ & $795 \pm 37$ \\
7 & $667 \pm 33$ & $879 \pm 43$ & $649 \pm 39$ & $939 \pm 21$ \\
& & Water loss (g) for second cycle & \\
0 & $0 \pm 0$ & $0 \pm 0$ & $0 \pm 0$ & $0 \pm 0$ \\
1 & $56 \pm 15$ & $86 \pm 15$ & $56 \pm 21$ & $82 \pm 17$ \\
2 & $136 \pm 24$ & $192 \pm 20$ & $116 \pm 23$ & $199 \pm 19$ \\
3 & $188 \pm 22$ & $281 \pm 20$ & $170 \pm 20$ & $283 \pm 6$ \\
4 & $270 \pm 31$ & $384 \pm 46$ & $247 \pm 22$ & $405 \pm 11$ \\
5 & $371 \pm 44$ & $592 \pm 54$ & $362 \pm 31$ & $607 \pm 10$ \\
6 & $507 \pm 39$ & $849 \pm 57$ & $505 \pm 33$ & $857 \pm 29$ \\
7 & $641 \pm 50$ & $1004 \pm 58$ & $641 \pm 48$ & $1017 \pm 25$
\end{tabular}

zSmall = diameter of 0.374 inch $(0.95 \mathrm{~cm})$ and length of 1.125 inches $(2.86 \mathrm{~cm})$. Large = diameter of 0.874 inch $(2.22 \mathrm{~cm})$ and length of 3.0 inches $(7.62 \mathrm{~cm}) ; 10 \mathrm{~g}=0.35 \mathrm{oz}$. 
T able 4. Substrate tension readings for chrysanthemum ( $D$ endranthema grandiflora) 'C oral C harm' grown in 3.4-qt (3-L) containers with either a 2 pine bark : 1 C anadian peat : 1 sand substrate (PBPS, by volume) or MetroMix 500 (M M) with small or large ceramic $\operatorname{cups}^{2}(n=4 \pm S D)$.

\begin{tabular}{lcccc}
\hline Day & Small/PBPS & Small/M M & Large/PB PS & Large/M M \\
\hline & & Tension readings $(\mathrm{kPa})$ first cycle & \\
0 & $1.3 \pm 0.3$ & $0.9 \pm 0.5$ & $0.6 \pm 0.4$ & $1.0 \pm 0.3$ \\
1 & $1.2 \pm 0.5$ & $1.4 \pm 0.3$ & $0.8 \pm 0.5$ & $1.4 \pm 0.5$ \\
2 & $1.6 \pm 0.5$ & $1.6 \pm 0.4$ & $1.3 \pm 0.4$ & $2.1 \pm 0.5$ \\
3 & $3.0 \pm 0.9$ & $2.4 \pm 0.7$ & $1.3 \pm 0.5$ & $2.6 \pm 0.5$ \\
4 & $3.2 \pm 0.8$ & $5.3 \pm 2.1$ & $2.5 \pm 0.6$ & $5.9 \pm 1.0$ \\
5 & $6.4 \pm 2.0$ & $8.6 \pm 1.8$ & $3.8 \pm 1.2$ & $13.3 \pm 0.8$ \\
6 & $6.4 \pm 1.3$ & $10.2 \pm 1.7$ & $6.8 \pm 1.7$ & --- \\
7 & $10.2 \pm 0.7$ & $11.8 \pm 3.7$ & 10.7 & -- \\
& & Tension readings (kPa) second cycle & \\
0 & $0.7 \pm 0.5$ & $0.6 \pm 0.2$ & $0.6 \pm 0.5$ & $1.0 \pm 0.7$ \\
1 & $1.3 \pm 0.5$ & $1.2 \pm 0.6$ & $1.0 \pm 0.4$ & $1.5 \pm 0.4$ \\
2 & $2.5 \pm 0.7$ & $1.8 \pm 0.9$ & $1.2 \pm 0.4$ & $2.2 \pm 0.5$ \\
3 & $2.4 \pm 0.9$ & $2.2 \pm 0.7$ & $1.5 \pm 0.5$ & $2.6 \pm 0.6$ \\
4 & $2.0 \pm 0.5$ & $3.6 \pm 1.0$ & $1.6 \pm 0.6$ & $4.1 \pm 0.7$ \\
5 & $3.6 \pm 1.3$ & $11.7 \pm 3.7$ & $2.5 \pm 1.0$ & $14.0 \pm 0.4$ \\
6 & $6.3 \pm 1.0$ & $17.1 \pm 6.1$ & $5.5 \pm 1.8$ & --- \\
7 & $8.8 \pm 2.6$ & $33.7 \pm 16.2$ & $10.6 \pm 2.8$ & --
\end{tabular}

${ }^{2}$ Small $=$ diameter of 0.374 inch $(0.95 \mathrm{~cm})$ and length of 1.125 inches $(2.86 \mathrm{~cm})$. L arge = diameter of 0.874 inch $(2.22 \mathrm{~cm})$ and length of 3.0 inches $(7.62 \mathrm{~cm})$.

$\mathrm{y}_{\mathrm{n}}=1,1 \mathrm{bar}=100 \mathrm{kPa}$.

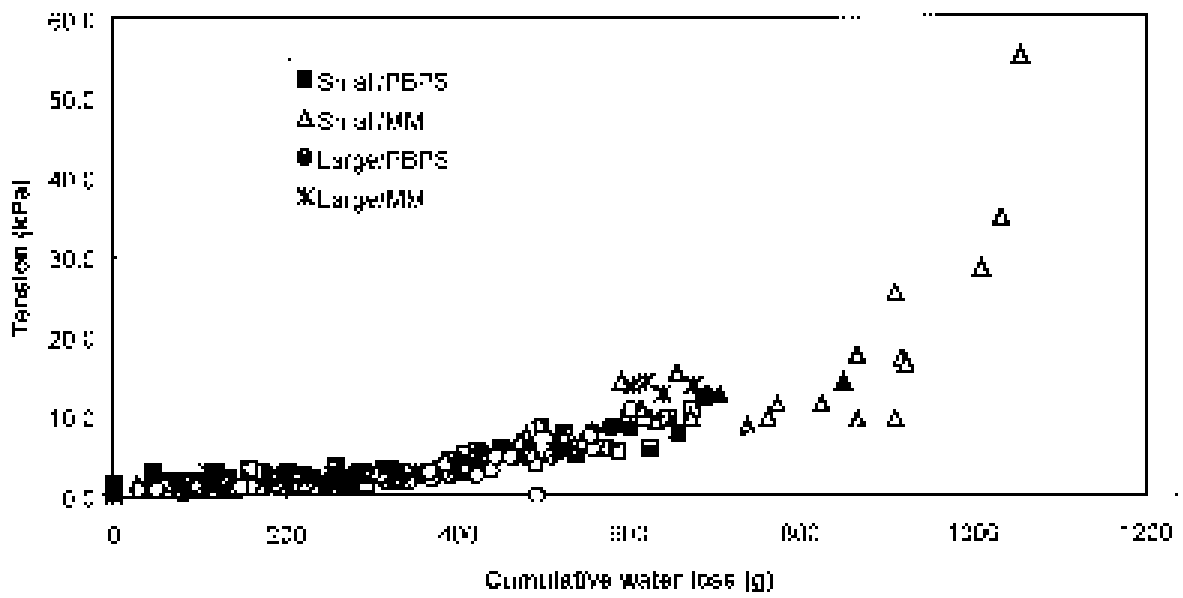

Fig. 3. R elationship between substrate tension ( $\mathrm{kPa}$ ) and cumulative water loss for chrysanthemum ( $D$ endranthema grandiflora) ' $C$ oral $C$ harm' in the first and second cycle with small [diameter of 0.374 inch $(0.95 \mathrm{~cm})$ and length of 1.125 inches $(2.86 \mathrm{~cm})$ ] or large [diameter of 0.874 inch $(2.22 \mathrm{~cm})$ and length of 3.0 inches $(7.62 \mathrm{~cm})]$ ceramic cups in 2 pine bark : $1 \mathrm{C}$ anadian peat : 1 sand (PB PS, by volume) or M etro-M ix 500 (M M). 1 bar $=100 \mathrm{kPa}$. significant $(P \leq 0.05)$ for days 2 to 7 of the first cycle and days 1 to 7 of the second cycle. Thisiscontraryto Expt. 1, and is likely due to chrysanthemum roots exploiting the total container volume and not just the upper portion of the substrate as occurred with azalea. Consequently, morewater wasextracted from the M etro-M ix 500 because that substrate had a higher water holding capacity than PBPS. Tension readings were not different $(P \leq 0.05)$ for sensors on days 0 to 7 of both cycles. H owever, it should be noted that tensions broke for the large sensors at day 6 . D ata for each day are shown in Tables 3 and 4 and a scatter plot is presented in Fig. 3.

WATER TENSION AND PCML RELATIONSHIP. D ata for chrysanthemum in $M$ etro-M ix 500 was used to evaluate a relationship between tension readings and percent of cumulative water loss. $D$ ata generated with both sensors and both cycles were used for this analysis. Figure 4 shows the relationship between water tension and PCWL. The following exponential function below gave the best fit for this relationship: $\Psi_{s}$ $=27.18 \mathrm{e}^{-0.0336 \mathrm{PCWL}}, \mathrm{R}^{2}=0.92$, where $\Psi_{\mathrm{s}}^{\mathrm{s}}$ $=$ substrate tension $(\mathrm{kPa})$.

This equation can be used to define the value of the substrate water tension to start an irrigation event as a function of how much water will be availablefor the chrysanthemum plants. In Fig. 4, the function has a good fit for low values of tensions or high values of PCWL, which would occur shortly after a irrigation event. For example, at a PCWL of $60 \% 40 \%$ of the water at container capacity had been lost and would correspond to a depletion of water available to the plant in most

Fig. 4. R elationship between tension ( $\mathrm{kPa}$ ) and percent of cumulative water loss (PC WL) for chrysanthemum ( D endranthema grandiflora) 'C oral C harm' grown in Metro-Mix 500. 1 bar $=100 \mathrm{kPa}$.
T ables 1 and 2 and a scatter plot of the experimental data is shown in Fig. 2.

EXPERIMENT 2. Cumulative water loss and substrate tension readings for each day were tested for substrate $x$ sensor interaction. For thefirst dry down cycle, interactions for water loss were not highly significant $(P \leq 0.01)$ and the only highly significant interaction for tension occurred on day $5(P=0.003)$. There were no significant $(P \leq 0.05)$ interactions for water loss or tensions during the second dry down cycle. Cumulative water loss due to substrate was

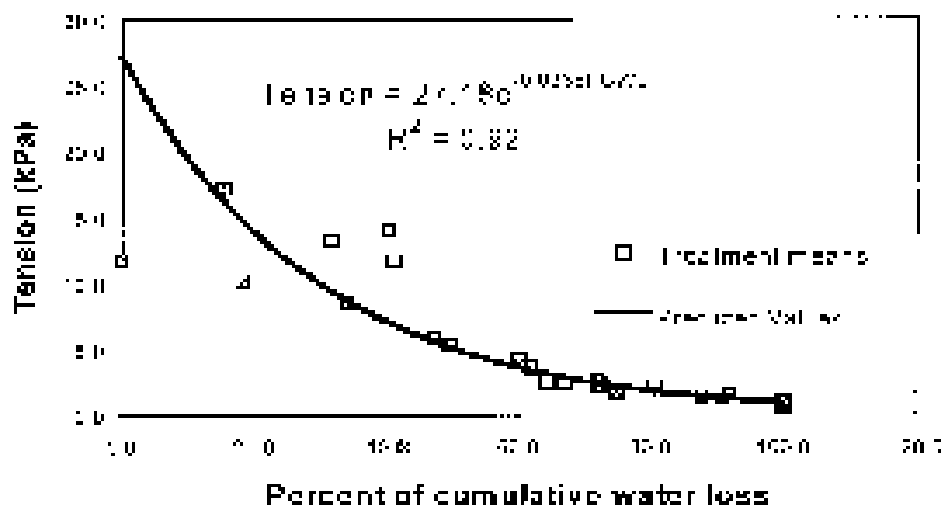

Hortlechnology • January-M arch 1999 9(1) 
container substrates, indicating theneed for irrigation.

\section{Conclusions}

O ur data indicate that tensiometric ceramic cups 0.374 inch in diameter and 1.125 inches long or 0.874 inch in diameter and 3.0 inches long, may be used for monitoring the moisture tension of M etro-M ix 500 or 2 pine bark: 1 Canadian peat : 1 sand substrates. Tensiometers were inserted horizontallyin the center of the substratein 3.4qt plastic containers. This required a minimal amount of time to cut a hole in the container sidewall and position a tensiometer. Tensiometers functioned reliably during the experiments, but for large ceramic cups, the tension may break near 0.1 bar (10 kPa). H owever, in most soilless substrates, water availability would be limited at this tension. Establishing the relationship between tension and available water would enable nursery operators to use real-time measurements to control irrigation for maximum water use efficiency.

\section{Literature cited}

Beeson, Jr., R.C. 1992. Restricting overhead irrigation to dawn limits growth in container-grown woody ornamentals. H ortScience 27(9):996-999.

Burger, D.W. and J.L. Paul. 1987. Soil moisture measurements in containers with solid-state, electronic tensiometers. H ortScience 22(2):309-310.

Karam, N.S. and A.X. N iemiera. 1994. Cyclic sprinkler irrigation and pre-irrigation substrate water content affect water and $\mathrm{N}$ leaching from containers. J. Environ. $\mathrm{H}$ ort. 12(4):198-202.

Lieth, J.H . and D.W. Burger. 1989. Growth of chrysanthemum using an irrigation system controlled by soil moisture tension. J . Amer. Soc. H ort. Sci. 114(3):387-397.

M eron, M., R. Assaf, B. Bravdo, R. Wallach, P. H allel, A. Levin, and I. D ahan. 1995. Soil sensor actuated microirrigation of apples, $p$. 486- 491. In: Proc. Fifth Intl. Microirrigation Congr., Amer. Soc. Agr. Eng., St. Joseph, M ich.

Phene, C.J ., C.P. Allee, and J . Pierro. 1988. $M$ easurement of soil matric potential and real timeirrigation scheduling, p. 63-75. In: Sensors \& techniquesfor irrigation management. Ctr. Irr. Technol. Publ. 880502. Calif. State U niv., Fresno, Calif.
Pogue, W.R. and S.G. Pooley. 1988. Tensiometricmanagement of soil water, p. 175180. In: Sensors\& techniquesfor irrigation management. Ctr. Irr. Technol. Publ. 880502. Calif. State U niv., Fresno, Calif.

Richards, S.J . and A.W. M arsh. 1961. Irrigation based on soil suction measurements. Proc. Soil Sci. Soc. Amer. 25:65-69.

Stone, K.C., A.G. Smajstrla, and F.S. Zazueta. 1985. M icrocomputer-based data acquisition system for continuous soil water potential measurements. Proc. Soil Crop Sci. Soc. Fla. 44:49-53.

Stone, K.C., A.G. Smajstrla, and F.S. Zazueta. 1986. Entrapped air and ceramic cup effects on tensiometer response times. Proc. Soil Crop Sci. Soc. Fla. 46: 26-29.

Testezlaf, R., B.M . Jacobson, F.S. Zazueta, and T.H. Yeager. 1995. A graphical user interface for real-time irrigation control in greenhouses. Proc. Soil Crop Sci. Soc. Fla. 55:59-62.

T estezlaf, R., F.S. Zazueta, and T.H . Yeager. 1996. A real-time irrigation control system for greenhouses, p. 204-211. In: Proc. Sixth Intl. Conf. Computers Agr., Amer. Soc. Agr. Eng., St. J oseph, M ich.

T estezlaf, R., F.S. Zazueta, and T.H . Yeager. 1997. A real-time irrigation control system forgreenhouses. A ppl. Eng. Agr. 13(3):329332.

Valiente, J.I . 1993. Evaluation of a capacitive-type soil moisture sensor for horticulture use. M S thesis. U niv. of Fla., Gainesville.

Vellidis, G., A.G. Smajstrla, and F.S. Zazueta. 1990. Continuoussoil water potential measurement with a micro-computer based data acquisition system. Appl. Eng. Agr. 6(6):733-738.

Watson, K.K. 1967. Response behavior of a tensiometer-pressure transducer system under conditions of changing air pressure. Soil Sci. 104:439-443.

Watson, K.K. and R.D . Jackson. 1967. T emperature effects in a tensiometer-pressure transducer system. Proc. Soil Sci. Soc. Amer. 31:156-160.

Zazueta, F.S., A.G. Smajstrla, and D.S. $\mathrm{H}$ arrison. 1985. M icrocomputer control of trickle irrigation systems, p. 511-515. In: Proc. 3rd I ntl. D rip/ Trickle Irr. Congr., Amer. Soc. Agr. Eng., St. J oseph, M ich.

Zazueta, F.S., T.H. Yeager, J.I. Valiente, and J.A. Brealey. 1994. A modified tensiometer for irrigation control in potted ornamental production. Proc. Soil C rop Sci. Soc. Fla. 53:36-39. 